\title{
The Clinical Relevance of Periostin in Asthma
}

Irene Braithwaite, PhD, Ruth Semprini, MBBS and Richard Beasley, DSc

Medical Research Institute of Nerw Zealand, Wellington, New Zealand

\section{ABSTRACT}

Periostin is a matricellular protein which is generated by airway epithelial cells in response to interleukin (IL)-4 and IL-13. Serum periostin levels have been proposed as a biomarker of type-2 inflammation with clinical utility in severe asthma. Normal reference ranges have been established in a predominant Caucasian population using the Elecsys ${ }^{\circledR}$ Periostin immunoassay. Periostin levels do not differentiate asthma from non-asthma, or mild-to-moderate asthma from severe asthma, although they are higher in adults with asthma who have raised levels of blood eosinophils and fractional exhaled nitric oxide (FeNO). Periostin status can predict response to monoclonal antibody therapy directed against IL-13 and immunoglobulin E ( $\operatorname{IgE})$, such that adults with severe asthma and a periostin level $\geq 50 \mathrm{ng} / \mathrm{ml}$ (designated "periostin-high") have a greater therapeutic response than "periostin-low" patients. The clinical relevance of these findings is uncertain, due to the similar predictive ability of the more commonly available biomarkers blood eosinophils and/or FeNO. (BRN Rev. 2018;4(4):258-73)

Corresponding author: Richard Beasley, richard.beasley@mrinz.ac.nz

Key words: Asthma. Biomarkers. Periostin. Phenotypes. 


\section{INTRODUCTION}

In asthma, biomarkers have played a pivotal role in the identification of clinical phenotypes, risk stratification of patients, prediction of treatment responsiveness to therapies, monitoring of disease and new drug development ${ }^{1,2}$. An effective biomarker must be objectively measurable and allow evaluation as an indicator of normal or pathological processes or treatment responsiveness ${ }^{3}$. Traditional biomarkers in asthma have included induced sputum and blood eosinophil levels, total and allergen specific serum immunoglobulin $\mathrm{E}$ (IgE), and fraction of exhaled nitric oxide $(\mathrm{FeNO})^{1,2}$.

More recently, periostin has been identified as a biomarker with possible clinical utility in severe asthma ${ }^{4-10}$. Periostin is a matricellular protein which is generated by airway epithelial cells, partly regulated by interleukin (IL)-13 and IL- 4 and is detectable in serum. Serum periostin levels may identify patients with a high risk of forced expiratory volume in one second $\left(\mathrm{FEV}_{1}\right)$ decline ${ }^{11}$ and increased risk of asthma exacerbation despite inhaled corticosteroids (ICS) therapy ${ }^{12}$. It may also identify those with eosinophilic airway inflammation and those with eosinophilic infiltration of the lung parenchyma and sputum eosinophilia ${ }^{5}$. Periostin gene expression is reduced with ICS therapy ${ }^{4}$, and serum periostin levels are reduced with inhaled ${ }^{13}$ and systemic ${ }^{14}$ glucocorticoid treatment. High serum periostin levels may also indicate responsiveness to monoclonal antibody therapies targeting the type-2 inflammatory pathway, including IL-13 ${ }^{12,15,16}$ and $\operatorname{IgE} E^{17}$.

There is substantive evidence that periostin is associated with and contributes to type- 2 dependent inflammation in asthma. The gene coding for periostin (POSTN) is among the most highly upregulated genes in the airway of asthma patients compared to non-asthmatics $^{18}$. Interleukin-4 and IL-13 cytokines are key in regulating the expression of periostin in airway epithelial cells ${ }^{19}$. Periostin is also secreted in vitro by primary lung fibroblasts and cell lines in response to IL-4 and IL-136. In a chronic asthma mouse model, type- 2 inflammatory cytokines IL-4 and IL-13 induce upregulation of the POSTN gene ${ }^{6}$ causing increased circulating periostin which in turn binds not only to bronchial smooth muscle ${ }^{20,21}$, but also to integrins on eosinophils, promoting eosinophilic localisation and adhesion to the airways ${ }^{10}$ and consequent pulmonary inflammation and fibrosis ${ }^{22,23}$. Over-expression of periostin in epithelial cells also results in the stimulation of transforming growth factor-beta (TGF-b), which in turn stimulates secretion of type-1 collagen by airway fibroblasts $^{24}$. The structure of periostin is critical in the type-2 inflammatory pathway. Periostin has a splicing domain at its C-terminal, four fasciclin- 1 domains in the middle and a cysteine-rich domain at its $\mathrm{N}$-terminal ${ }^{25}$. The cysteine-rich domains bind integrin proteins, thereby regulating cell adhesion and mobility $^{26}$ assisting with connective tissue remodelling and repair.

However, periostin is not specific to asthma or the airway epithelium. Various isomers can be found in skeletal muscle ${ }^{27}$, the myocardi$\mathrm{um}^{28}$, heart valves ${ }^{29}$, skin $^{30}$, bone $\mathrm{e}^{31}$, and periodontal ligaments ${ }^{32}$. Periostin is increased in many patients with conditions associated with high levels of cell division and turnover, such as cancers and fibroblastic proliferation ${ }^{7,33-35}$. This ubiquity raises the risk that disruption 
of other human systems may affect serum periostin levels and confound interpretation in the clinical context of asthma.

Additionally, a number of periostin assays have been used in asthma research, of which only two have published data with respect to stability and variability ${ }^{36,37}$, and none are commercially available for clinical practice currently. To justify its development as a commercially available test, periostin must show its value as uniquely superior to other type-2 biomarkers in identifying asthma phenotypes which preferentially respond to specific asthma treatments and monitor their response to such treatments.

The purpose of this review is to discuss what is known about periostin, both in the absence and presence of asthma, and to assess the clinical utility of periostin as a biomarker in the management of asthma.

\section{WHAT IS KNOWN ABOUT PERIOSTIN IN ADULTS WITHOUT ASTHMA?}

The normal reference range of periostin has been determined in a sample of 480 predominantly European adults ${ }^{38}$, in accordance with the Clinical and Laboratory Standards Institute guidelines for determining reference values and reference intervals for quantitative clinical laboratory tests ${ }^{39}$ using the Elecsys ${ }^{\circledR}$ Periostin immunoassay (Roche Diagnostics, Penzberg, Germany $^{36}$ ). Adults with asthma, chronic obstructive pulmonary disease (COPD) and comorbidities that might putatively result in increased periostin levels were excluded from the study. In this population the distribution of serum periostin was relatively wide, with a marked right skew distribution (Fig. 1a). The median (interquartile range [IQR]) periostin level was 50.1 (43.1 to 56.9$) \mathrm{ng} / \mathrm{ml}$, with a five-fold range of 28.1 to $136.4 \mathrm{ng} / \mathrm{ml}$, and the $90 \%$ confidence limits were 35.0 to $71.1 \mathrm{ng} / \mathrm{ml}$. There was no association between serum periostin levels and age, sex or common non-respiratory comorbidities, but serum periostin levels were lower in current smokers and lower in those with a high body mass index (BMI), consistent with other studies ${ }^{40-42}$. A related study showed a modest reduction in serum periostin levels in the evening, compared with morning testing $(46.2 \mathrm{ng} / \mathrm{ml}$ at $1800 \mathrm{hr}$ versus $50.5 \mathrm{ng} / \mathrm{ml}$ at $0800 \mathrm{hr})^{43}$.

Trends towards higher periostin levels in adults without asthma who identify as "Asian" have been observed ${ }^{38}$. This trend was confirmed in a dedicated study showing that the median (IQR) periostin level in non-asthmatic Chinese is 59.6 [ 50.3 to 67.9$] \mathrm{ng} / \mathrm{ml}$, which is approximately $17 \%$ higher than Caucasians (49.7 [42.8 to 56.5$] \mathrm{ng} / \mathrm{ml})^{44}$. Unlike Caucasians, periostin levels were sex-dependent in the Chinese group, with median (IQR) periostin levels of 61.3 [51.8 to 73.1$] \mathrm{ng} / \mathrm{ml}$ and 55.2 [46.4 to $58.3 \mathrm{ng} / \mathrm{ml}$ in females and males respectively. Japanese women also have higher levels of periostin than their male counterparts ${ }^{42}$ but no comparison has been made of periostin levels in Japanese with Caucasians.

\section{Influence of bone disease}

Periostin was first identified in mouse osteoblasts and originally called osteoblastic-specific factor $2^{32}$. Not surprisingly, a number of consequent studies have investigated the relationship between serum periostin and states 

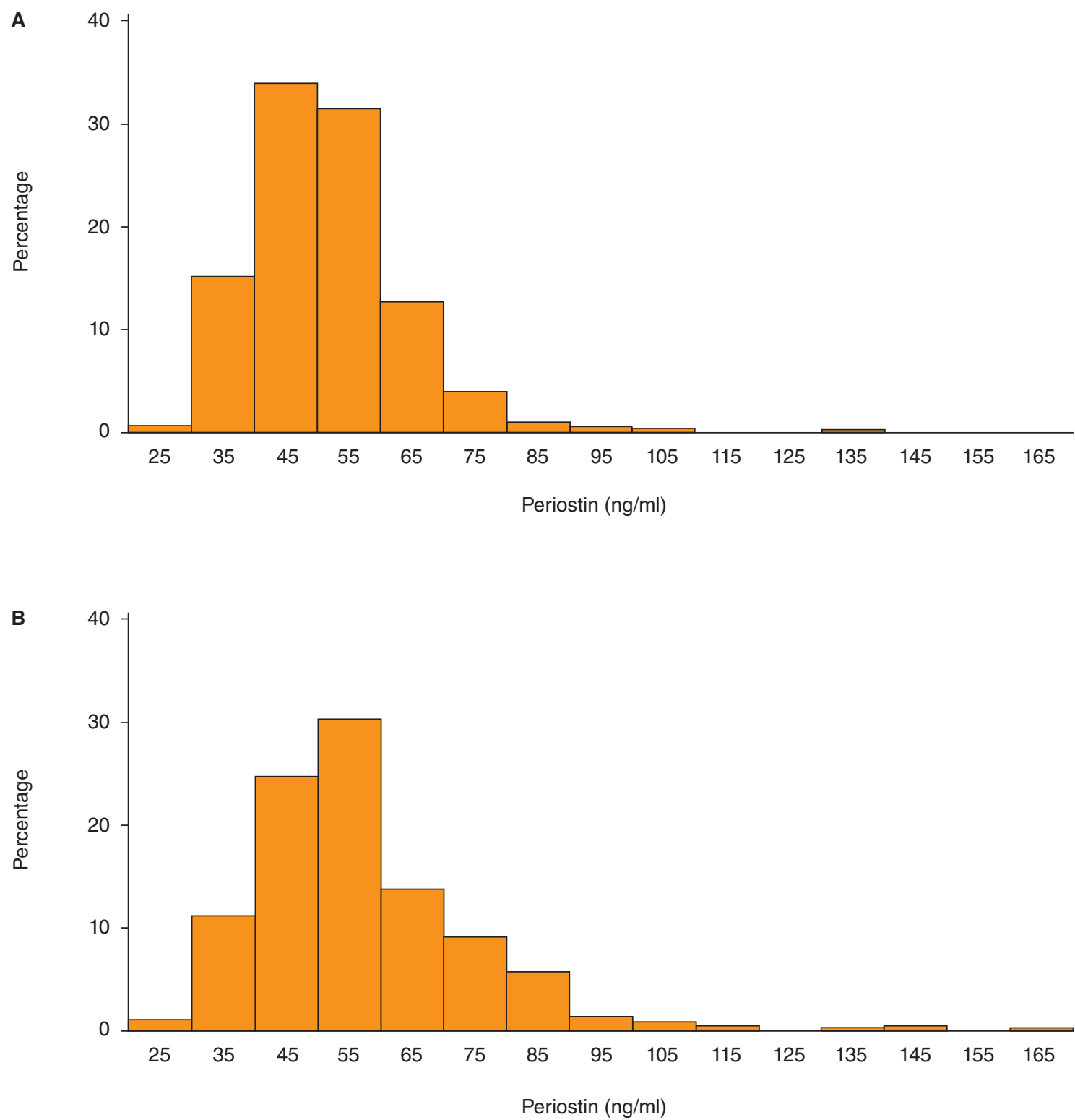

FIGURE 1. Distribution of serum periostin in a population: a) without asthma or COPD (reproduced from Caswell-Smith $R$ et al. ${ }^{38}$; permission conveyed through Copyright Clearence Center, Inc.); b) with symptomatic airflow obstruction (reproduced from Fingleton $\mathrm{J}$ et al. ${ }^{13}$ with permission from (C)ERS 2018).

of bone disease $\mathrm{e}^{27,45}$. Periostin levels are lower in those with osteoarthritis of the knee and in progressive osteoarthritis ${ }^{46}$, but are elevated in post-menopausal women with non-vertebral osteoporotic fractures ${ }^{47}$ and in the early stages after hip fracture ${ }^{48}$. In joint replacement surgery, periostin levels show a biphasic response, characterised by an initial fall, then increasing to almost double baseline levels by eight weeks, and remaining 
risen at 26 weeks post-surgery ${ }^{49}$. In long bone fractures, a similar time course is followed, with periostin levels reaching a (lesser) maximum level at eight weeks, whereas in small bone fractures, there is a brief initial dip, with a return to stable levels at two weeks ${ }^{49}$. Thus a history of the timing and extent of recent bone injury needs to be considered in the interpretation of serum periostin levels.

\section{Influence of type-2 inflammatory related conditions}

Allergic rhinitis in non-asthmatics, but not in asthmatics, is associated with higher periostin levels ${ }^{42}$. Periostin has been implicated in the inflammatory and fibrotic pathways of atopic dermatitis ${ }^{50}$, psoriasis $^{51}$ and chronic rhino-sinusitis with nasal polyps ${ }^{52,53}$. Whether these and other type-2 related conditions result in elevated periostin levels compared to those without the disease is yet to be elucidated.

\section{Summary of non-asthma findings}

A clinician can utilise serum periostin levels in an adult Caucasian patient without consideration of sex or age. In Chinese patients, one would expect periostin levels to be about $20 \%$ higher than those of Caucasians, and for Chinese women to have levels approximately $15 \%$ higher than Chinese men. Similarly, Japanese women have higher periostin levels than Japanese men. Periostin levels should be interpreted with caution in those with osteoarthritis, and it would be prudent to wait at least six months after joint surgery and large bone fractures to assess periostin levels. Periostin levels are lower in smokers and in those with elevated BMIs. The effect of other type-2 inflammatory conditions such as allergic rhinitis on serum periostin levels is not yet certain. The time of day a blood sample is taken is unlikely to confound interpretation of the result.

\section{WHAT IS KNOWN ABOUT PERIOSTIN IN ADULTS WITH ASTHMA?}

\section{Asthma versus non-asthma}

In adults with symptomatic airflow obstruction, most of whom had a doctor's diagnosis of asthma, the distribution of serum periostin is relatively wide (Fig. $1 b)^{12}$. In studies of predominantly Caucasian adults with asthma using the Elecsys ${ }^{\circledR}$ Periostin immunoassay the median (IQR) periostin levels were between 47.7 (40.2 to 56.3) ng/ml and 54 (46 to 62) $\mathrm{ng} / \mathrm{ml}$ (Table 1) $)^{13-15,17,38,43,44,49,54-57}$. This is similar to a predominant Caucasian non-asthma population in which the median (IQR) level of 50.1 (43.1 to 56.9) $\mathrm{ng} / \mathrm{ml}$ has been derived $^{38}$. In Chinese adults with asthma the median (IQR) level is 56.8 (47.8 to 70.4$) \mathrm{ng} / \mathrm{ml}$ compared to 57.0 (50.3 to 67.9) $\mathrm{ng} / \mathrm{ml}$ in Chinese adults without asthma ${ }^{44}$. Thus serum periostin levels cannot distinguish between those with asthma from those without.

\section{Asthma severity}

In a direct comparison of periostin levels in patients with and without asthma of differing severity, the median (IQR) periostin levels were 53 (44 to 62$) \mathrm{ng} / \mathrm{ml}$ and 54 (46 to 62 ) $\mathrm{ng} / \mathrm{ml}$ 
TABLE 1. Serum periostin levels in study participants using the Elecsys ${ }^{\circledR}$ Periostin immunoassay

\begin{tabular}{|c|c|c|}
\hline Population & $\begin{array}{c}\text { Median (IOR) } \\
\mathrm{ng} / \mathrm{ml}\end{array}$ & $\begin{array}{c}\text { Mean (SD) } \\
\mathrm{ng} / \mathrm{ml}\end{array}$ \\
\hline \multicolumn{3}{|l|}{ Non-asthmatic participants } \\
\hline Non-asthmatic: $n=16$ (Caswell-Smith et al. ${ }^{43}$ ) & 49.4 (42.5 to 62.7$)$ & $50.5(13.0)$ \\
\hline Non-asthmatic: $n=27$ (Simpson et al. ${ }^{55}$ ) & 49 (46 to 65$)$ & - \\
\hline No diagnosis of respiratory disease: $n=480$ (Caswell-Smith et al. ${ }^{38}$ ) & 50.1 (43.1 to 56.9$)$ & $51.2(11.9)$ \\
\hline Non-asthmatic, 26 weeks post small bone fracture: $n=24$ (Varughese et al. ${ }^{49}$ ) & $50.0(44.2$ to 54.4$)$ & $53.0(14.8)$ \\
\hline Non-asthmatic awaiting joint surgery baseline: $n=34$ (Varughese et al. ${ }^{49}$ ) & 49.1 (39.3 to 62.0$)$ & $54.2(18.0)$ \\
\hline Non-asthmatic, 26 weeks post large bone fracture: $n=30$ (Varughese et al. ${ }^{49}$ ) & 51.4 (45.8 to 67.3$)$ & $56.0(16.3)$ \\
\hline Chinese non-asthmatic: $n=120$ (Semprini et al. ${ }^{44}$ ) & - & $59.6(15.4)$ \\
\hline \multicolumn{3}{|l|}{ Patients with undifferentiated obstructive respiratory disease } \\
\hline Undifferentiated obstructive respiratory disease: $n=386$ (Fingleton et al. ${ }^{13}$ ) & $54.0(45.1$ to 65.6$)$ & $57.3(18.6)$ \\
\hline Subgroup: no diagnosis of asthma: $n=101$ & 54.6 (44.5 to 63.9$)$ & $56.3(16.1)$ \\
\hline Subgroup: doctor-diagnosed asthma: $\mathrm{n}=285$ & $53.7(45.2$ to 65.7$)$ & $57.7(19.4)$ \\
\hline Undifferentiated obstructive respiratory disease: $n=389$ (Wagener et al. $\left.{ }^{58}\right)$ & 54.3 (45.2 to 65.8$)$ & 57.3 \\
\hline Subgroup: obese comorbid: $n=54$ & 53.5 (45.9 to 68.2 ) & $51.7(11.5)$ \\
\hline Subgroup: asthma-COPD overlap: $n=33$ & $55.2(47.3$ to 63.0$)$ & $56.1(15.7)$ \\
\hline Subgroup: mild intermittent asthma: $n=73$ & 53.5 (48.1 to 63.9$)$ & $56.9(18.8)$ \\
\hline Subgroup: mild atopic asthma: $n=145$ & $55.2(43.7$ to 65.1$)$ & $57.6(17.7)$ \\
\hline Subgroup: moderate-to-severe atopic asthma: $n=53$ & 54.4 (43.4 to 67.8$)$ & $63.8(25.2)$ \\
\hline \multicolumn{3}{|l|}{ Asthma patients } \\
\hline Asthma: doctor-diagnosed asthma: $\mathrm{n}=285$ (Fingleton et al. ${ }^{13}$ ) & 53.7 (45.2 to 65.7$)$ & $57.7(19.4)$ \\
\hline Mild-to-moderate asthma: $n=110$ (Fingleton et al. ${ }^{56}$ ) & $47.7(40.2$ to 56.3$)$ & \\
\hline $\begin{array}{l}\text { Unstable asthma within } 48 \text { hours of severe exacerbation and treatment: } n=34 \\
\text { (Johansson et al. }{ }^{54} \text { ) }\end{array}$ & 48.9 (42.2 to 66.6$)$ & $54.6(21.5)$ \\
\hline Moderate-to-severe asthma: $n=37$ (Fingleton et al. ${ }^{56}$ ) & $50.8(45.7$ to 60.4$)$ & \\
\hline On GINA treatment step 3 to $5: n=83$ (Fingleton et al. ${ }^{57}$ ) & 51.6 (41.8 to 62.6$)$ & \\
\hline Non-severe asthma: $n=75$ (Simpson et al. ${ }^{55}$ ) & 53 (44 to 62 ) & \\
\hline Severe asthma: $n=51$ (Simpson et al. ${ }^{55}$ ) & 54 (46 to 62$)$ & \\
\hline On ICS and LABA: $n=60$ (Semprini et al. ${ }^{14}$ ) & $48.9(41.6$ to 60.3$)$ & $52.2(16.4)$ \\
\hline On ICS and LABA: $n=16$ (Caswell-Smith et al. ${ }^{43}$ ) & $51.7(41.5$ to 63.7$)$ & $53.5(13.6)$ \\
\hline Chinese, stable asthma, range of severity: $n=68$ (Semprini et al. ${ }^{44}$ ) & $56.8(47.8$ to 70.4$)$ & $59.9(16.3)$ \\
\hline Uncontrolled asthma on ICS (LAVOLTA I by treatment group: $n=1081$, Hanania et al. ${ }^{16}$ ) & $\begin{array}{l}53.8 \text { (44 to } 66) \\
53.7 \text { (45 to } 66) \\
52.7 \text { (45 to } 67)\end{array}$ & \\
\hline Uncontrolled asthma on ICS (LAVOLTA II by treatment group: $n=1067$, Hanania et al. ${ }^{16}$ ) & $\begin{array}{l}55.3 \text { (44 to } 69) \\
54.4 \text { (44 to } 69) \\
54.2 \text { (44 to } 70)\end{array}$ & \\
\hline
\end{tabular}


TABLE 1. Serum periostin levels in study participants using the Elecsys ${ }^{\circledR}$ Periostin immunoassay (continuation)

\begin{tabular}{|l|c|c|}
\hline Population & $\begin{array}{c}\text { Median (IOR) } \\
\mathrm{ng} / \mathrm{ml}\end{array}$ & $\begin{array}{c}\text { Mean (SD) } \\
\mathrm{ng} / \mathrm{ml}\end{array}$ \\
\hline Uncontrolled severe persistent allergic asthma: omalizumab trials: $\mathrm{n}=534$ (Hanania et al. ${ }^{17}$ ) & - & - \\
\hline Subgroup: eosinophils $<260 / \mu \mathrm{L}: \mathrm{n}=383$ & - \\
\hline Subgroup: eosinophils $\geq 260 / \mu \mathrm{L}: \mathrm{n}=414$ & - \\
\hline Subgroup: FeNO $<19.5 \mathrm{ppb}: \mathrm{n}=193$ & $48(14)$ \\
\hline Subgroup: FeNO $\geq 19.5 \mathrm{ppb}: \mathrm{n}=201$ & $58(20)$ \\
\hline $\begin{array}{l}\text { Uncontrolled asthma despite the use of medium- to-high-dose inhaled glucocorticoids } \\
\text { and a second controller: lebrikizumab trials: pooled data } \mathrm{n}=463 \text { (Corren et al. }{ }^{15} \text { ) }\end{array}$ & $49(15)$ \\
\hline
\end{tabular}

Footnote: The variable periostin assays used in the literature make comparative assessments of serum periostin levels between studies difficult. However, by limiting those studies in asthma patients where serum periostin levels were determined using the clinical trial version of the Elecsys ${ }^{\circledR}$ Periostin immunoassay (Roche Diagnostics, Penzberg, Germany) it is possible to make comparisons. This assay was developed according to the guidelines of the Clinical and Laboratory Institute (CLSI) and is a fully automated immunoassay operated on the e601 module of the cobas 6000 system equipped with software version $05-01$ or higher ${ }^{36}$. It has a high repeatability with coefficients of variation across multiple sites and reagent lots of 1.7 to $3.1 \%$.

COPD: chronic obstructive pulmonary disease; FeNO: fractional exhaled nitric oxide; GINA: Global Initiative for Asthma; ICS: inhaled corticosteroids; IQR: interquartile range; LABA: long-acting beta agonist; LAVOLTA: Efficacy and safety of lebrikizumab in patients with uncontrolled asthma; ppb: parts per billion; standard deviations (SD) are referred between parentheses.

in those with non-severe and severe asthma respectively (Fig. 2) ${ }^{54}$.

Similarly, patients with severe uncontrolled allergic asthma despite at least Global Initiative for Asthma (GINA) step 4 treatment have comparable serum periostin levels to adults with mild-to-moderate asthma (Table 1$)^{55}$. In a study of patients with symptomatic obstructive respiratory disease, those with a diagnosis of asthma (285 of 386) had a median (IQR) periostin of 53.7 (45.2 to 65.7$) \mathrm{ng} / \mathrm{ml}^{12}$. When this population was phenotypically characterised by cluster analysis $^{56}$, three distinct asthma phenotypes became apparent: mild intermittent asthma, mild atopic asthma and moderate-to-severe atopic asthma, with median (IQR) periostin levels of 53.5 (48.1 to 63.9), 55.2 (43.7 to 65.1) and 54.4 (43.4 to 67.8) $\mathrm{ng} / \mathrm{ml}$ respectively. While the highest periostin levels were in the moderate-to-severe atopic asthma group, the large range of values between the groups resulted in considerable overlap with the other asthma phenotypes.

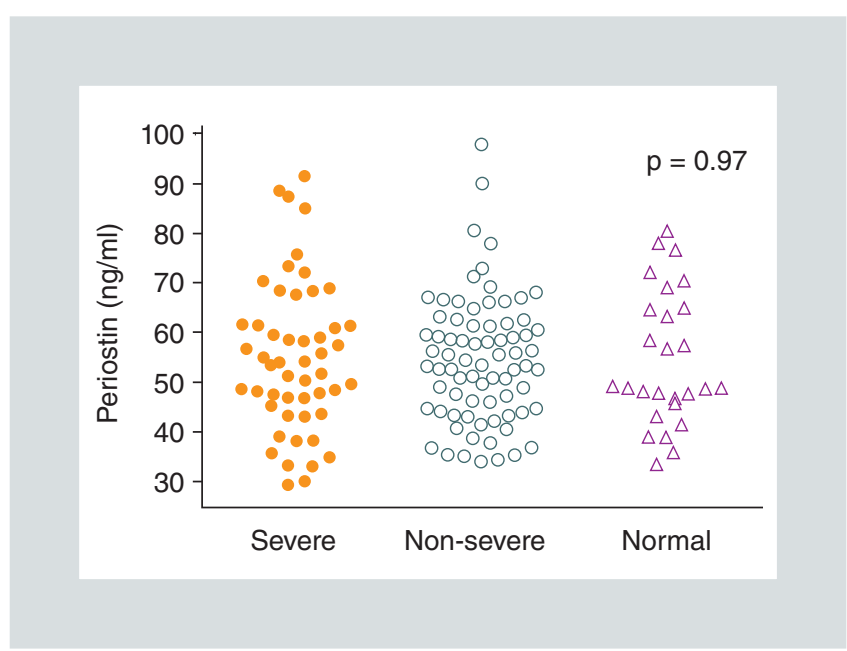

Figure 2. Serum periostin in subjects with severe asthma, non-severe asthma and no asthma (reproduced from Johansson MW et al. ${ }^{54}$ with permission from Elsevier).

\section{Associations with other type-2 biomarkers}

In asthma there are weak associations between serum periostin and other type-2 biomarkers such as FeNO, serum total IgE and blood eosinophil count (Fig. 3) ${ }^{13,54}$. In severe asthma 
A

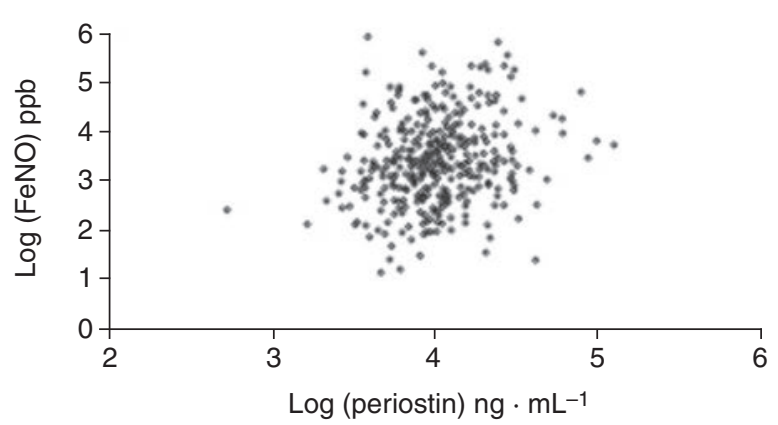

C

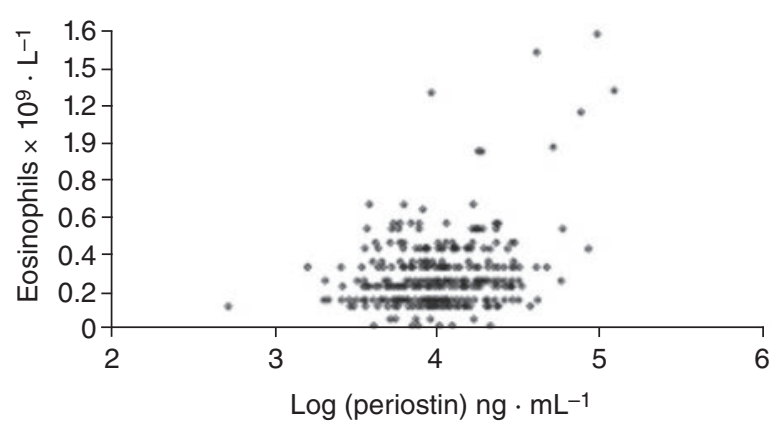

B

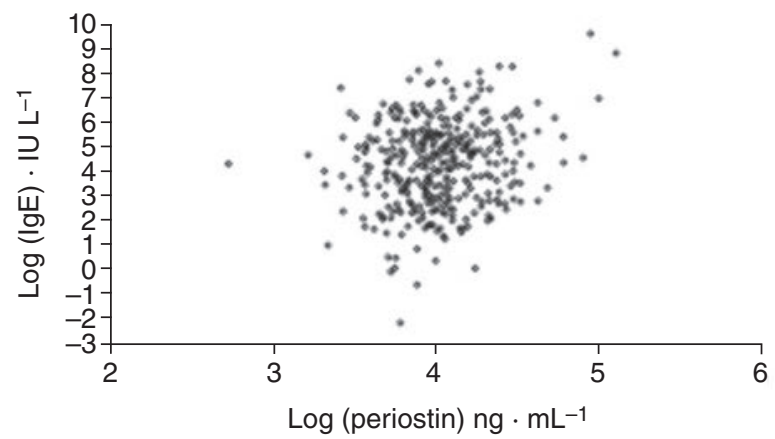

D

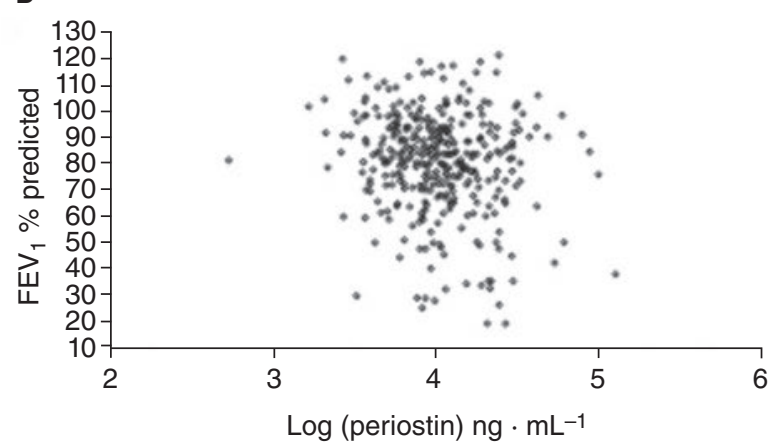

Figure 3. The association between $\log$ serum periostin and a) $\log$ FeNO, b) $\log \lg E$, c) blood eosinophil count and d) forced expiratory volume in one second $\left(\mathrm{FEV}_{1}\right.$ ) (reproduced from Fingleton $J$ et al..$^{13}$ with permission from (OERS 2016).

FeNO: fractional exhaled nitric oxide; IU: international unit; ppb: part per billion.

populations, the serum periostin level is higher in the subgroups of patients with a strong type-2 phenotype, characterised by raised blood eosinophil and FeNO levels ${ }^{17}$. This suggests that these biomarkers identify both similar and different aspects of type- 2 inflammation in asthma. This interpretation is consistent with the observations that anti-IL-13 therapy results in a reduction in serum periostin and $\mathrm{FeNO}$ but not eosinophil levels ${ }^{15}$, whereas anti-IL5 reduces eosinophils and not $\mathrm{FeNO}^{59}$.

\section{Within-patient variation}

The intra-participant coefficient of variation of serum periostin levels is approximately $6 \%$ in adults with stable asthma patients on ICS/ long-acting $\beta_{2}$-agonist (LABA) treatment when measured repeatedly over an eight-week period (Fig. 4) ${ }^{13}$. Similarly, within-patient variations of $5 \%$ and $5.3 \%$ have been reported in poorly controlled asthmatics despite treatment with ICS ${ }^{14}$ and in patients with severe asthma refractory to ICS treatment ${ }^{5}$. This suggests 


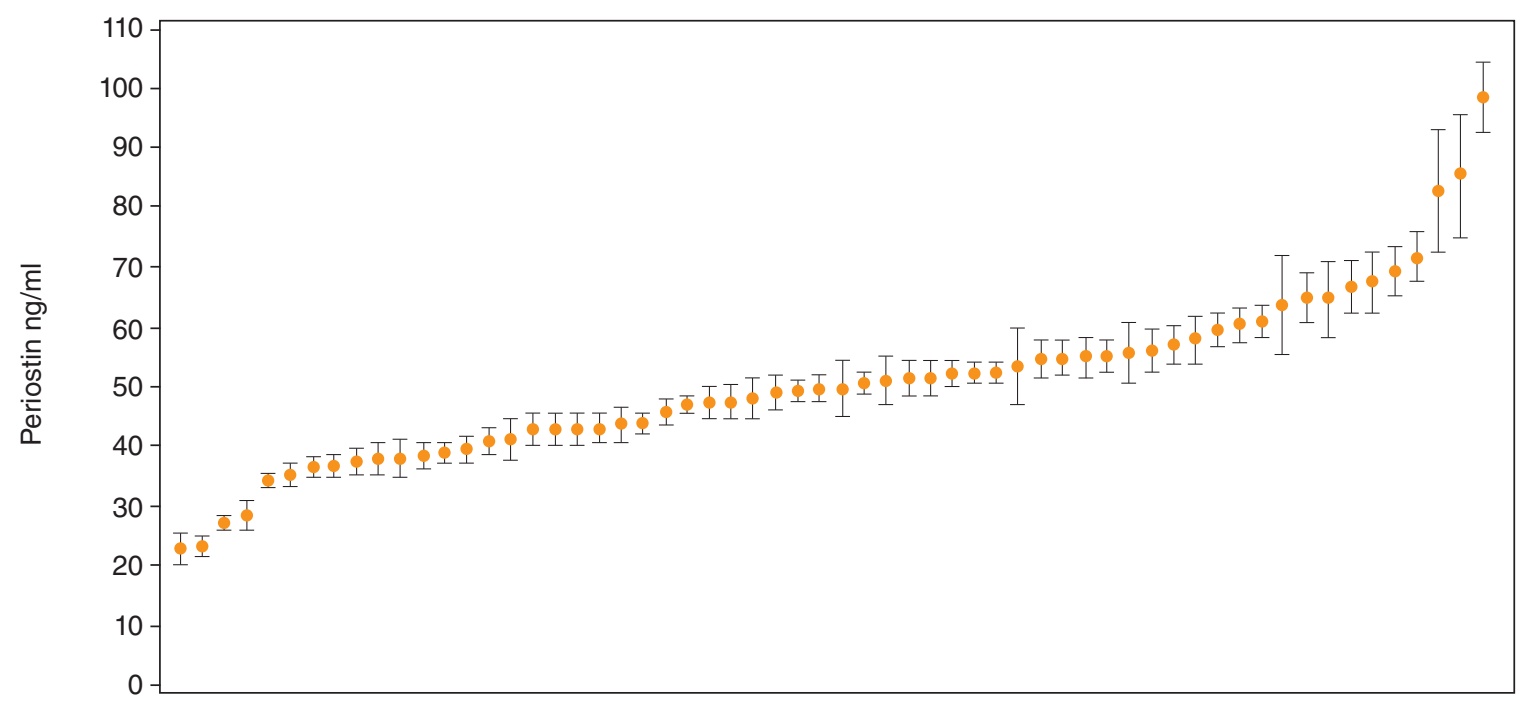

FIGURE 4. Individual patient mean periostin levels \pm 1 SD ranked by mean periostin level measured on eleven occasions over eight weeks (reproduced from Semprini $R$ et al. ${ }^{14}$ with permission from Elsevier).

SD: standard deviation.

that serum periostin is a stable biomarker in adult asthma.

\section{Diurnal variation}

As with healthy adults, mean serum periostin levels in asthma patients reduce gradually during the day with a fall of approximately $5 \%$, from $53.5 \mathrm{ng} / \mathrm{ml}$ at $0800 \mathrm{hr}$ to $50.9 \mathrm{ng} / \mathrm{ml}$ at $1800 \mathrm{hr}^{43}$. This daytime variation is similar to that observed in other type-2 biomarkers such as sputum and blood eosinophils ${ }^{60-64}$, and $\mathrm{FeNO}^{65-67}$ which are higher in the early morning compared with late afternoon or evening. This suggests that the time of day in which a blood sample is taken is unlikely to influence clinical decision-making for asthma patients.

\section{Seasonal variation}

Three studies have assessed whether there is any seasonal variation in periostin levels taken from asthmatic patients. There was no evidence of seasonal variation in a study of asthma patients prescribed ICS/LABA therapy conducted over a 15 -month peri$\operatorname{od}^{13}$, in asthmatics who suffered an asthma exacerbation which was conducted over an 11-month period ${ }^{54}$, or in asthma patients prescribed long-term ICS over an eight-year period $^{11}$. This contrasts with findings related to 
$\operatorname{IgE}$, where seasonal variation does occur, attributed to variations in allergen exposures $^{68,69}$.

\section{Response to steroid treatment}

Serum periostin levels decrease by $5 \%$ in steroid naïve asthma patients after the introduction of the ICS fluticasone propionate 400 mcg daily ${ }^{9}$, and by about $10 \%$ after 12 weeks of the ICS budesonide $800 \mathrm{mcg}$ daily ${ }^{12}$. Periostin levels also fall by approximately $10 \%$ in patients on ICS therapy who are treated with systemic glucocorticoids during an asthma exacerbation ${ }^{13}$ and between $15 \%$ and $17 \%$ in asthmatic patients treated with systemic glucocorticoids after presenting a severe exacerbation of asth$\mathrm{ma}^{9,54}$. Thus, both inhaled and oral glucocorticoids result in a modest reduction in serum periostin levels in asthma.

\section{Predicting responsiveness to monoclonal antibody therapies}

The concept that the presence of high periostin levels may identify patients who are likely to respond to monoclonal antibody treatment directed against type- 2 inflammation ${ }^{4}$ was confirmed by a randomised controlled trial (RCT) of lebrikizumab (anti-IL-13 therapy) in adults with moderate-to-severe asthma and uncontrolled symptoms despite ICS therapy ${ }^{14}$. The "periostin-high" patients (those with a periostin level $\geq 50 \mathrm{ng} / \mathrm{ml}$, the median observed in the patient cohort being analysed) had a greater improvement in $\mathrm{FEV}_{1}$ in the lebrikizumab treatment arm compared to placebo whereas the "periostin-low" patients did not (Fig. 5). This predictive ability was not limited to periostin, as in a post hoc analysis, high FeNO levels also identified patients who had greater improvements in lung function. The intra-patient variability in the two-week run-in period of the study was less for periostin than FeNO, indicating that periostin is a more stable biomarker. In the high $\mathrm{T}$ helper 2 (Th2) subgroup (defined by total serum IgE and blood eosinophil levels) the rate of exacerbations was $60 \%$ lower in the lebrikizumab group than in the placebo group $(p=0.03)$, with a trend towards a similar effect in the "periostin-high" group, with the exacerbation rate being $26 \%$ lower $(p=0.40)$.

These findings were extended in the subsequent replicate RCTs evaluating multiple doses of lebrikizumab in patients with uncontrolled asthma despite use of ICS and a second controller (Fig. 6a) ${ }^{15}$. Treatment with lebrikizumab reduced the rate of severe exacerbations compared to placebo (the primary outcome variable) which was more pronounced in the "periostin-high" patients (60\% reduction) than in the "periostin-low" patients ( $5 \%$ reduction). Lung function also improved following lebrikizumab treatment to a greater extent in "periostin-high" patients (increase in $\mathrm{FEV}_{1}$ of 9.1 versus $2.6 \%$ predicted). Raised FeNO and blood eosinophils were also predictive of treatment response to lebrikizumab.

More recently, two replicate phase 3 studies Efficacy and safety of lebrikizumab in patients with uncontrolled asthma (LAVOLTA I and II) have shown limitations in the use of periostin as a predictor of responsiveness to anti-IL-13 therapy, and the efficacy of lebrikizumab therapy ${ }^{16}$. In these replicate trials, 
A Total cohort

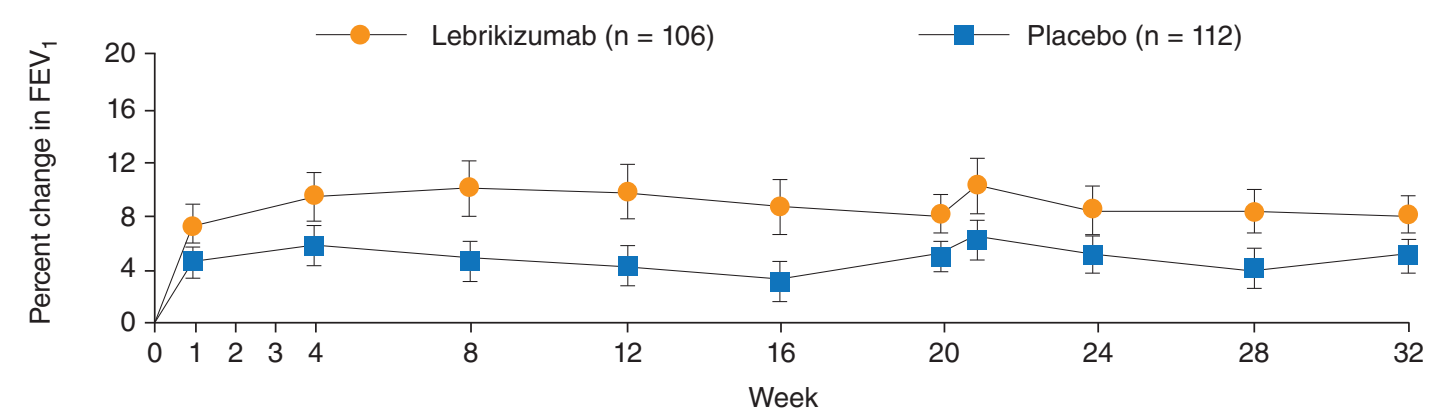

B High-periostin subgroup

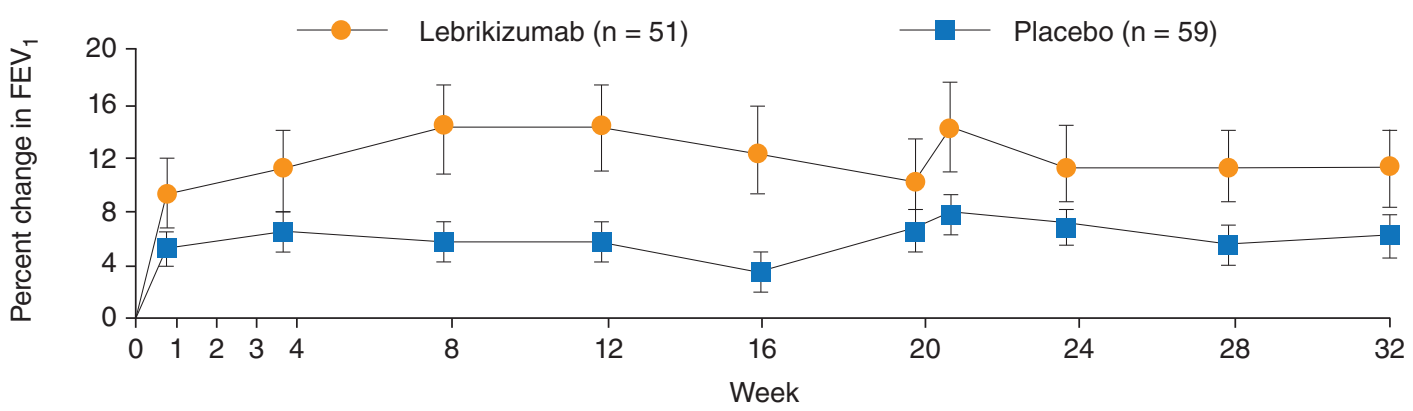

C Low-periostin subgroup

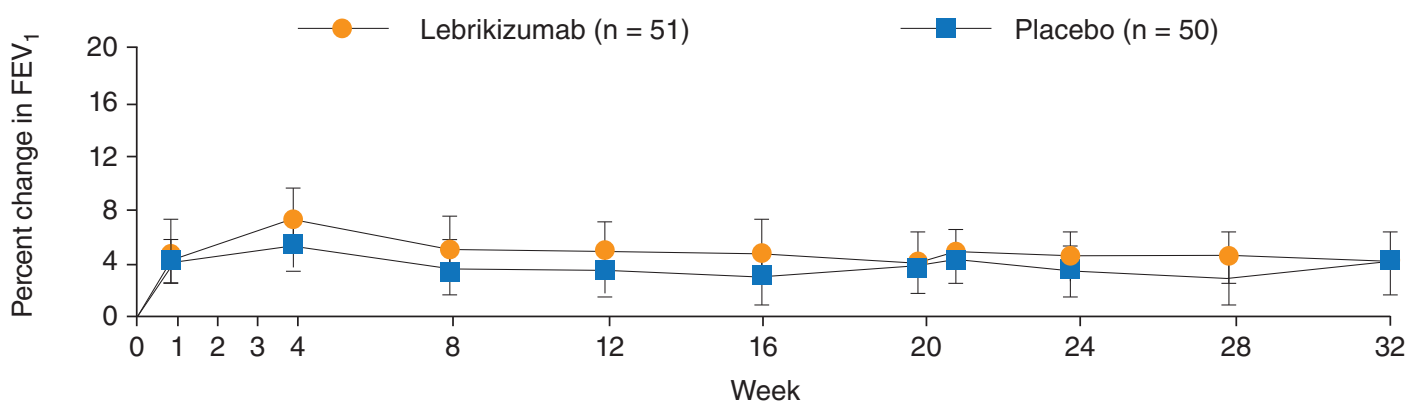

FIGURE 5. Change in FEV 1 with lebrikizumab therapy by periostin status. "Periostin-high" and "periostin-low" subgroups were defined by periostin levels $\geq 50$ or $<50 \mathrm{ng} / \mathrm{ml}$, the median periostin level of the population studied (reproduced from Corren $\mathrm{J}$ et al. ${ }^{15}$ with permission from (C) 2011 Massachusetts Medical Society).

$\mathrm{FEV}_{1}$ : forced expiratory volume in one second.

LAVOLTA I showed significantly reduced asthma exacerbation rates in "biomarker-high"' patients (periostin $\geq 50 \mathrm{ng} / \mathrm{ml}$ or blood eosinophils $\geq 300$ cells/uL) although there was not a clear distinction in efficacy between "biomarker-high" and "-low"' groups. In contrast, in LAVOLTA II, there was no significant reduction in exacerbation risk in "biomarker-high" 
patients, although lebrikizumab showed greater benefit in the "biomarker-high" group than the "biomarker-low" group. There were similar findings, regardless of whether the data were analysed separately as a "periostin-high" or composite "blood eosinophil or periostin-high" group. Although the treatment-by-biomarker interaction analysis failed to reach statistical significance, the strongest interaction was observed for blood eosinophils. In both trials there was a significant improvement in $\mathrm{FEV}_{1}$ with lebrikizumab compared with placebo in "biomarker-high" patients, suggesting that anti-IL-13 treatment may have more effect on airflow obstruction than on exacerbation risk.

Similar findings were observed in a study of the efficacy of tralokinumab, another monoclonal antibody directed against IL-13 ${ }^{70}$. Although tralokinumab did not significantly reduce exacerbation rates in patients with severe uncontrolled asthma, $\mathrm{FEV}_{1}$ was improved. In a post hoc analysis of the subgroups with raised periostin ( $\geq$ median periostin level), improvements in lung function were greatest in patients with airway reversibility at baseline and not receiving longterm oral glucocorticoids. In the replicate phase 3 trials of tralokinumab in patients with severe uncontrolled asthma ${ }^{71}$, STRATOS 1 identified a baseline FeNO measure of $\geq 37 \mathrm{ppb}$ as the "preferred" biomarker, with a $44 \%$ reduction in annual exacerbation rate in this group compared to placebo. In STRATOS 2, a reduction in annualised exacerbations rates in this same "FeNO-high" group was not seen raising questions as to the applicability of FeNO as a predictive biomarker for this treatment, while periostin analyses have not yet been reported.
The ability of serum periostin to predict responsiveness to monoclonal antibody therapy beyond IL-13 was demonstrated in the post hoc analysis of a large RCT of omalizumab, an anti-IgE therapy, in patients with uncontrolled severe persistent allergic asthma (Fig. 6b) ${ }^{17}$. After 48 weeks of omalizumab, reductions in exacerbations were greater in the "high" versus "low" subgroups for all three biomarkers: periostin (30 versus 3\%), FeNO (53 versus 16\%), and blood eosinophils (32 versus 9\%). Previous investigations have shown that potential biomarkers, including allergen-specific IgE, total $\mathrm{IgE}$, serum tryptase, eosinophil cationic protein and soluble CD23, were not able to predict the therapeutic response to omalizumab ${ }^{17}$.

The ability of serum periostin to predict responsiveness has also been assessed with dupilumab, a monocloncal antibody directed against IL-4 alpha chain receptor (IL-4R $\alpha$ ), thereby inhibiting both IL-4 and IL-13 signalling. Dupilumab reduced exacerbations in both "periostin-high" and "periostin-low" patient subgroups ( $\geq$ and $<$ median periostin respectively) ${ }^{72}$. Similarly the efficacy of dupilum$\mathrm{ab}$ in reducing exacerbations was comparable in the groups defined by blood eosinophil levels $\geq$ and $<300 / \mathrm{uL}$ respectively ${ }^{73}$. In the most recent phase 3 study $^{74}$, dupilumab improved $\mathrm{FEV}_{1}$ at 12 weeks and reduced annual exacerbation rates in all patients, with a greater effect in patients with blood eosinophils $\geq 300 / \mathrm{uL}$, while periostin analyses are yet to be reported.

\section{Asthma exacerbation risk}

Higher serum periostin levels have consistently been associated with an increased risk of asthma exacerbation in clinical trials of 

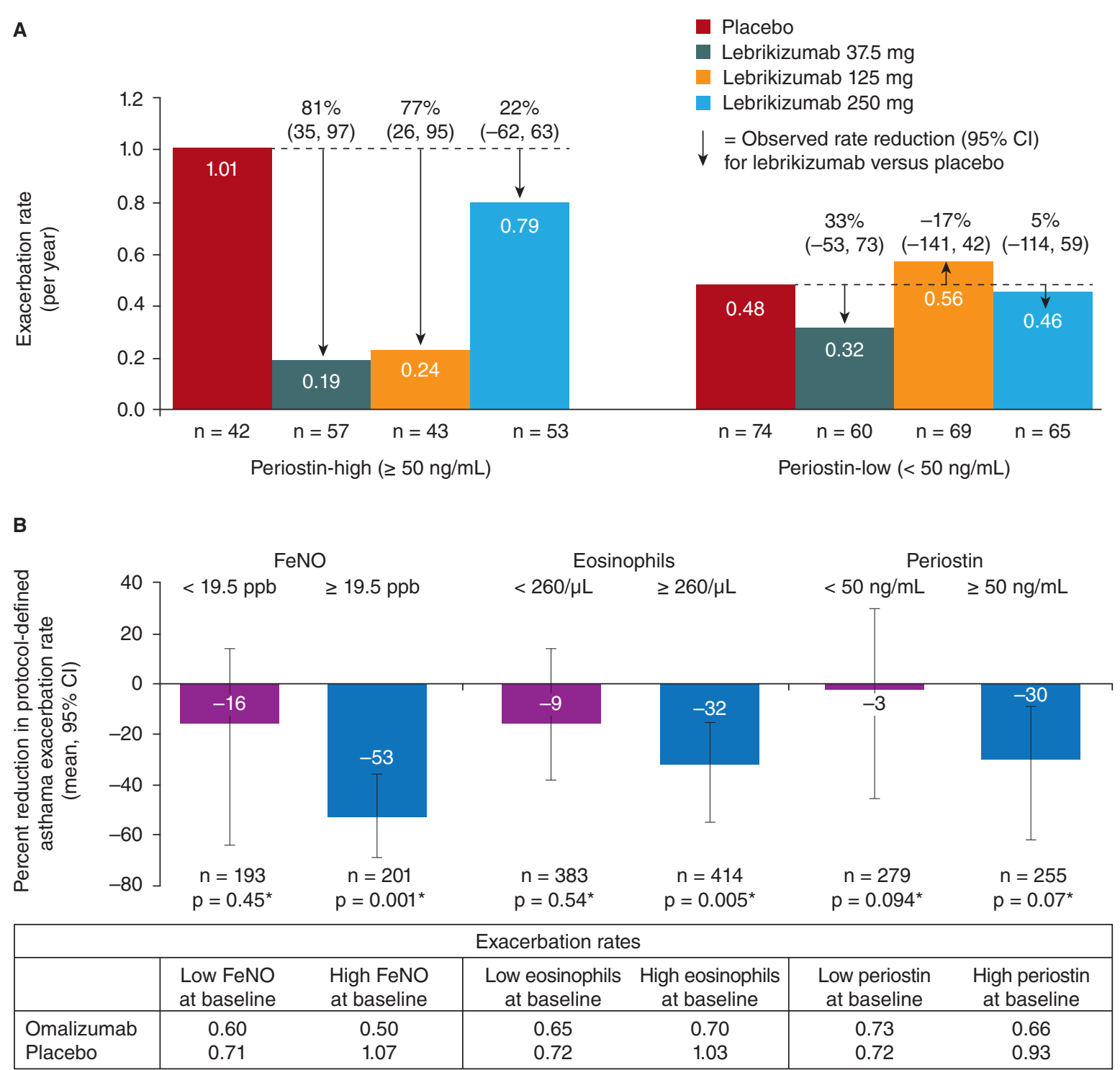

FigURE 6. Rate of asthma exacerbations with a) lebrikizumab therapy by periostin status (reproduced with permission from BMJ Publishing Group Limited of Hanania NA et al. ${ }^{12}$; permission conveyed through Copyright Clearance Center, Inc.), b) omalizumab therapy by FeN0, blood eosinophil and periostin status (reproduced from Hanania NA et al. ${ }^{17}$, with permission of the American Thoracic Society (C2018 American Thoracic Society). "Periostin-high" and "periostin-low" subgroups were defined by periostin levels $\geq 50 \mathrm{or}<50 \mathrm{ng} / \mathrm{ml}$. $\mathrm{Cl}$ : confidence interval; FeNO: fractional exhaled nitric oxide.

monoclonal antibody therapy in adults with uncontrolled severe persistent allergic asth$\mathrm{ma}^{15,17,70,72,73-75}$. However, this has not been borne out in a cohort of asthma patients with predominantly mild asthma, in whom higher periostin levels are associated with a longer time to exacerbation ${ }^{76}$. This suggests that high levels of serum periostin predict increased risk of severe exacerbations in patients with severe asthma but not in mild asthma. 


\section{Summary of asthma findings}

There is a wide range in serum periostin levels in adult asthma, similar to that observed in a non-asthma population. Periostin levels are relatively stable and the time of day or the time of year in which blood sampling is done is unlikely to confound interpretation of the results. Periostin levels fall by up to $10 \%$ with the initiation of ICS therapy in ICS-naïve patients, and by up to $15 \%$ with the initiation of oral CS treatment after an asthma exacerbation. There is no discernible difference in periostin levels between those who have asthma and those who do not, nor is there a discernible pattern of increasing periostin levels with increasing asthma severity. While ICS treatment suppresses periostin levels, this is unlikely to completely explain the lack of difference in periostin levels between those with severe asthma and mild-to-moderate asthma, and those without asthma. While periostin is a predictor of exacerbations in severe asthma, this has not been borne out in a more generalised mild-to-moderate asthma population.

The ability of "'periostin-high" levels to predict responsiveness to monoclonal antibody therapies targeting the type-2 inflammatory pathway, anti-cytokine IL-13 and anti-IgE has the greatest potential for the use of this measurement in clinical practice. However, the observation that the more widely available type- 2 biomarkers, blood eosinophils and possibly FeNO, also have predictive ability for anti-IL-13 and anti-IgE therapies means that the place of periostin for this purpose is uncertain. Furthermore, blood eosinophils predict responsiveness to anti-IL-5 therapy ${ }^{77}$, but not anti-epithelial-cell derived cytokine thymic stromal lymphopoietin (TSLP) therapy ${ }^{78}$.
Together, this means that specific biomarkers cannot help guiding which of the existing therapies should be used. This is disappointing as it would have been ideal to have one specific biomarker for each monoclonal antibody therapy with a corresponding biomarker "readout" indicating the therapy to which the patient is most likely to respond.

\section{CONCLUSIONS}

Periostin levels do not distinguish those with asthma from those without, nor do they allow evaluation of disease severity. Periostin levels may be helpful in categorising the type-2 status of patients with severe asthma and may also predict treatment responsiveness to monoclonal antibody treatment directed against IL-13 and IgE in patients with severe persistent allergic asthma, although blood eosinophils and FeNO have similar predictive capability. From the current evidence available, serum periostin should be interpreted with caution when incorporating into decision-making about treatment for asthma patients, as levels may differ according to the assay used, will change with bony injury, and may vary between ethnicities making interpretation of levels problematic.

\section{ACKNOWLEDGEMENTS}

The MRINZ has received research funding from Genentech Inc for studies of the clinical relevance of periostin. The MRINZ receives independent research organisation funding from the Health Research Council of New Zealand. 


\section{CONFLICTS OF INTEREST}

\section{Dr. Beasley reports grants from Health Research Council of New Zealand, grants and personal fees from Astra Zeneca, grants and personal fees from GlaxoSmith Kline and grants from Ge- nentech; outside the submitted work. Dr. Sem- prini has nothing to disclose. Dr. Braithwaite has nothing to disclose.}

\section{REFERENCES}

1. Taylor DR, Barnes PJ, Bleecker ER et al. Using biomarkers in the assessment of airways disease. J Allergy Clin Immunol. 2011;128:927-34.

2. Szefler SJ, Wenzel S, Brown R et al. Asthma outcomes: Biomarkers. J Allergy Clin Immunol. 2012;129:S9-23.

3. Biomarkers Definitions Working Group. Biomarkers and surrogate endpoints: Preferred definitions and conceptual framework. Clin Pharmacol Ther. 2001;69:89-95.

4. Woodruff PG, Modrek B, Choy DF et al. T-helper Type 2-driven Inflammation Defines Major Subphenotypes of Asthma. Am J Respir Crit Care Med. 2009;180:388-95.

5. Jia G, Erickson RW, Choy DF et al. Periostin is a systemic biomarker of eosinophilic airway inflammation in asthmatic patients. J Allergy Clin Immunol. 2012;130:647-54.e10.

6. Takayama G, Arima K, Kanaji T et al. Periostin: A novel component of subepithelial fibrosis of bronchial asthma downstream of IL-4 and IL-13 signals. J Allergy Clin Immunol. 2006;118:98-104.

7. Nair P, Kraft M. Serum periostin as a marker of $\mathrm{T}(\mathrm{H}) 2$-dependent eosinophilic airway inflammation. J Allergy Clin Immunol. 2012;130:655-6.

8. Li W, Gao P, Zhi Y et al. Periostin: its role in asthma and its potential as a diagnostic or therapeutic target. Respir Res. 2015;16:57.

9. Matsumoto H. Serum periostin: a novel biomarker for asthma management. Allergol Int. 2014;63:153-60.

10. Izuhara K, Conway SJ, Moore BB et al. Roles of periostin in respiratory disorders. Am J Respir Crit Care Med. 2016;193:949-56.

11. Kanemitsu Y, Matsumoto H, Izuhara K et al. Increased periostin associates with greater airflow limitation in patients receiving inhaled corticosteroids. J Allergy Clin Immunol. 2013;132:305-12.e3.

12. Hanania NA, Noonan M, Corren J et al. Lebrikizumab in moderate-to-severe asthma: pooled data from two randomised placebo-controlled studies. Thorax. 2015;70:748-56

13. Fingleton J, Braithwaite I, Travers J et al. Serum periostin in obstructive airways disease. Eur Respir J. 2016;47:1383-91.

14. Semprini R, Caswell-Smith R, Fingleton J et al. Longitudinal variation of serum periostin in adults with stable asthma. J Allergy Clin Immunol. 2017; 139:1687-8

15. Corren J, Lemanske RFR, Hanania NNA et al. Lebrikizumab Treatment in Adults with Asthma. N Engl J Med. 2011;365:1088-98.

16. Hanania NA, Korenblat P, Chapman KR et al. Efficacy and safety of lebrikizumab in patients with uncontrolled asthma (LAVOLTA I and LAVOLTA II): replicate, phase 3, randomised, double-blind, placebo-controlled trials. Lancet Respir Med. 2016;4:781-96.

17. Hanania NA, Wenzel S, Roseń $\mathrm{K}$ et al. Exploring the effects of omalizumab in allergic asthma: An analysis of biomarkers in the EXTRA study. Am J Respir Crit Care Med. 2013;187:804-11.
18. Woodruff PG, Boushey HA, Dolganov GM et al. Genome-wide profiling identifies epithelial cell genes associated with asthma and with treatment response to corticosteroids. Proc Natl Acad Sci U S A. 2007;104:15858-63.

19. Yuyama N, Davies DE, Akaiwa M et al. Analysis of novel disease-related genes in bronchial asthma. Cytokine. 2002;19:287-96.

20. Johansson MW, Annis DS, Mosher DF. Alpha(M) beta(2) integrin-mediated adhesion and motility of IL-5-stimulated eosinophils on periostin. Am J Respir Cell Mol Biol. 2013;48:503-10.

21. Sidhu SS, Yuan S, Innes A et al. Roles of epithelial cell-derived periostin in TGF- activation, collagen production, and collagen gel elasticity in asthma. Proc Natl Acad Sci. 2010;107:14170-5.

22. Conway SJ, Izuhara K, Kudo $\mathrm{Y}$ et al. The role of periostin in tissue remodeling across health and disease. Cell Mol Life Sci. 2014;71:1279-88.

23. Chiappori A, De Ferrari L, Folli C, Mauri P, Riccio AM, Canonica GW. Biomarkers and severe asthma: a critical appraisal. Clin Mol Allergy. 2015;13:20

24. Takeshita S, Kikuno R, Tezuka K, Amann E. Osteoblast-specific factor 2 cloning of a putative bone adhesion protein with homology with the insect protein fasciclin I. Biochem J. 1993;294( Pt 1):271-8.

25. Bonnet N, Standley KN, Bianchi EN et al. The matricellular protein periostin is required for sost inhibition and the anabolic response to mechanical loading and physical activity. J Biol Chem. 2009;284:35939-50.

26. Makita K, Mikami Y, Matsuzaki H et al. Mechanism of periostin production in human bronchial smooth muscle cells. Int Arch Allergy Immunol. 2018 175:26-35.

27. Özdemir C, Akpulat U, Sharafi P, Yildiz Y, Onbaşilar I, Kocaefe Ç. Periostin is temporally expressed as an extracellular matrix component in skeletal muscle regeneration and differentiation. Gene. 2014;553:130-9.

28. Stansfield WE, Andersen NM, Tang R-H, Selzman CH. Periostin is a novel factor in cardiac remodeling after experimental and clinical unloading of the failing heart. Ann Thorac Surg. 2009;88:1916-21.

29. Conway SJ, Doetschman T, Azhar M. The inter-relationship of periostin, TGF beta, and BMP in heart valve development and valvular heart diseases. ScientificWorldJournal. 2011;11:1509-24.

30. Elliott CG, Wang J, Guo $X$ et al. Periostin modulates myofibroblast differentiation during full-thickness cutaneous wound repair. J Cell Sci. 2012;125 $121-32$.

31. Merle B, Garnero P. The multiple facets of periostin in bone metabolism Osteoporos Int. 2012;23:1199-212.

32. Horiuchi K, Amizuka N, Takeshita S et al. Identification and characterization of a novel protein, periostin, with restricted expression to periosteum and periodontal ligament and increased expression by transforming growth factor beta. J Bone Miner Res. 1999;14:1239-49.

33. Ruan K, Bao S, Ouyang G. The multifaceted role of periostin in tumorigenesis. Cell Mol Life Sci. 2009;66:2219-30.

34. Shao R, Bao S, Bai $X$ et al. Acquired expression of periostin by human breast cancers promotes tumor angiogenesis through up-regulation of vascular endothelial growth factor receptor 2 expression. Mol Cell Biol. 2004;24:3992-4003.

35. Kudo Y, Ogawa I, Kitajima S et al. Periostin Promotes Invasion and Anchorage-Independent Growth in the Metastatic Process of Head and Neck Can cer. Cancer Res. 2006;66:6928-35.

36. Palme S, Christenson RH, Jortani SA et al. Multicenter evaluation of analytical characteristics of the Elecsys $(\circledR)$ Periostin immunoassay. Clin Biochem. 2017;50:139-44.

37. Jeanblanc NM, Hemken PM, Datwyler MJ et al. Development of a new ARCHITECT automated periostin immunoassay. Clin Chim Acta. 2017 464:228-35.

38. Caswell-Smith R, Hosking A, Cripps $\mathrm{T}$ et al. Reference ranges for serum periostin in a population without asthma or COPD. Clin Exp Allergy. 2016; 46:1303-14.

39, Sine H, Zakowski J, Horowitz GL et al. EP28-A3c: Defining, Establishing, and Verifying Reference Intervals in the Clinical Laboratory; Approved Guideline. Third Edition. Clin Lab Stand Inst. 2010.

40. Thomson NC, Chaudhuri R, Spears M, Haughney J, McSharry C. Serum periostin in smokers and never smokers with asthma. Respir Med. 2015;109:708-15 
41. James A, Janson C, Malinovschi A et al. Serum periostin relates to type-2 inflammation and lung function in asthma: Data from the large population-based cohort Swedish GA(2)LEN. Allergy. 2017;:1753-60.

42. Kimura H, Konno S, Makita $\mathrm{H}$ et al. Serum periostin is associated with body mass index and allergic rhinitis in healthy and asthmatic subjects. Allergol Int. 2017;1-7.

43. Caswell-Smith C, Cripps T, Charles T et al. Day-time variation of serum periostin in asthmatic adults treated with ICS/LABA and adults without asthma. Allergy, Asthma Clin Immunol. 2017;13:8.

44. Semprini R, Tan E, Varughese R et al. Periostin in asthmatic and non-asthmatic adults of Chinese descent: Poster Presentations Thoracic Society Australia and New Zealand Annual Scientific Meeting 2017. Respirology. 2017;22:114.

45. Nakazawa T, Nakajima A, Seki N et al. Gene expression of periostin in the early stage of fracture healing detected by cDNA microarray analysis. J Orthop Res. 2004;22:520-5.

46. Rousseau JC, Sornay-Rendu E, Bertholon C, Garnero P, Chapurlat R. Serum periostin is associated with prevalent knee osteoarthritis and disease incidence/ progression in women: The OFELY study. Osteoarthr Cartil. 2015;23:1736-42.

47. Kim BJ, Rhee Y, Kim CH et al. Plasma periostin associates significantly with non-vertebral but not vertebral fractures in postmenopausal women: Clinical evidence for the different effects of periostin depending on the skeletal site. Bone. 2015;81:435-41.

48. Yan J, Liu HJ, Li H et al. Circulating periostin levels increase in association with bone density loss and healing progression during the early phase of hip fracture in Chinese older women. Osteoporos Int. 2017;28:2335-41.

49. Varughese R, Semprini R, Cripps $\mathrm{T}$ et al. Serum periostin levels following bone fractures and joint replacements. Asthma, Allergy Clin Immunol. In Press Serum periostin levels following small bone fractures, long bone fractures and joint replacements: an observational study. Allergy Asthma \& Clin Immunol. 2018;14.

50. Yamaguchi Y. Periostin in Skin Tissue Skin-Related Diseases. Allergol Int. 2014;63:161-70.

51. Arima K, Ohta S, Takagi A et al. Periostin contributes to epidermal hyperplasia in psoriasis common to atopic dermatitis. Allergol. 2015;64:41-8.

52, Xu M, Chen D, Zhou H, Zhang W, Xu J, Chen L. The role of periostin in the occurrence and progression of eosinophilic chronic sinusitis with nasal polyps. Sci Rep. 2017;7:1-9.

53. Miłoński J, Zielińska-Bliźniewska H, Przybyłowska K et al. Significance of cyclooxygenase-2(COX-2), periostin (POSTN) and interleukin-4(IL-4) gene expression in the pathogenesis of chronic rhinosinusitis with nasal polyps. Eur Arch Otorhinolaryngol. 2015;272:3715-20.

54. Johansson MW, Evans MD, Crisafi GM, Holweg CTJ, Matthews JG, Jarjour NN. Serum periostin is associated with type 2 immunity in severe asthma. J Allergy Clin Immunol. 2016;137:1904-7e2.

55. Simpson JL, Yang IA, Upham JW et al. Periostin levels and eosinophilic inflammation in poorly-controlled asthma. BMC Pulm Med. 2016;16:67.

56. Fingleton J, Travers J, Williams $\mathrm{M}$ et al. Treatment responsiveness of phenotypes of symptomatic airways obstruction in adults. J Allergy Clin Immunol. 2015;136:601-9.

57. Fingleton J, Semprini R, Shortt N et al. Change in Type-2 inflammatory biomarkers following severe exacerbations of asthma. Respirology. 2018;23:150.

58. Wagener AH, de Nijs SB, Lutter R et al. External validation of blood eosinophils, $\mathrm{FE}(\mathrm{NO})$ and serum periostin as surrogates for sputum eosinophils in asthma. Thorax. 2015;70:115-20.

59. Haldar P, Brightling CE, Hargadon B et al. Mepolizumab and exacerbations of refractory eosinophilic asthma. N Engl J Med. 2009;360:973-84.

60. Panzer SE, Dodge AM, Kelly EAB, Jarjour NN. Circadian variation of sputum inflammatory cells in mild asthma. J Allergy Clin Immunol. 2003; 111:308-12.
61. Kelly EAB, Houtman JJ, Jarjour NN. Inflammatory changes associated with circadian variation in pulmonary function in subjects with mild asthma. Clin Exp Allergy. 2004;34:227-33.

62. Wempe JB, Tammeling EP, Koëter GH, Håkansson L, Venge P, Postma DS Blood eosinophil numbers and activity during 24 hours: effects of treatment with budesonide and bambuterol. J Allergy Clin Immunol. 1992;90:757-65.

63. Winkel P, Statland BE, Saunders AM, Osborn H, Kupperman H. Within-day physiologic variation of leukocyte types in healthy subjects as assayed by two automated leukocyte differential analyzers. Am J Clin Pathol. 1981;75: 693-700.

64. Uhrbrand H. The number of circulating eosinophils; normal figures and spontaneous variations. Acta Med Scand. 1958;160:99-104.

65. Pijnenburg MW, Floor SE, Hop WC, De Jongste JC. Daily ambulatory exhaled nitric oxide measurements in asthma. Pediatr Allergy Immunol. 2006; 17: 189-93.

66. ten Hacken NHT, Van Der Vaart H, Van Der Mark TW, Koëter GH, Postma DS. Exhaled nitric oxide is higher both at day and night in subjects with nocturnal asthma. Am J Respir Crit Care Med. 1998;158:902-7.

67. Saito J, Gibeon D, Macedo P, Menzies-Gow A, Bhavsar PK, Chung KF Domiciliary diurnal variation of exhaled nitric oxide fraction for asthma control. Eur Respir J. 2014;43:474-84.

68. Somville A, Machiels J, Gilles GG, Saint-Remy J-MR. Seasonal variation in specific IgE antiboies of grass-pollen hypersensitive patients depends on the steady state $\operatorname{IgE}$ concentration and is not related to clinical symptoms. J Allergy Clin Immunol. 1989;83:486-94.

69. van der Heide S, de Monchy JGR, de Vries K, Bruggink TM, Kauffman HF Seasonal variation in airway hyperresponsiveness and natural exposure to house dust mite allergens in patients with asthma. J Allergy Clin Immunol. 1994;93:470-5.

70. Brightling CE, Chanez P, Leigh R et al. Efficacy and safety of tralokinumab in patients with severe uncontrolled asthma: A randomised, double-blind, placebo-controlled, phase 2b trial. Lancet Respir Med. 2015;3:692-701.

71. Panettieri RA, Sjöbring U, Péterffy A et al. Tralokinumab for severe, uncontrolled asthma (STRATOS 1 and STRATOS 2): two randomised, double-blind, placebo-controlled, phase 3 clinical trials. Lancet Respir Med. 2018 May 18 pii: S2213-2600(18)30184-X. [Epub ahead of print]

72. Wenzel S, Swanson B, Teper A et al. Dupilumab reduces severe exacerbations in periostin-high and periositn-low asthma patients. Eur Respir J 2016;48:OA1798

73. Wenzel S, Castro M, Corren J et al. Dupilumab efficacy and safety in adults with uncontrolled persistent asthma despite use of medium-to-high-dose inhaled corticosteroids plus a long-acting $\beta 2$ agonist: a randomised double-blind placebo-controlled pivotal phase $2 \mathrm{~b}$ dose-ranging trial. Lancet 2016;388:31-44.

74. Castro M, Corren J, Pavord ID et al. Dupilumab efficacy and safety in moderate-to-severe uncontrolled asthma. N Engl J Med. 2018 May 21. [Epub ahead of print].

75. Pavord ID, Korn S, Howarth P et al. Mepolizumab for severe eosinophilic asthma (DREAM): a multicentre, double-blind, placebo-controlled trial Lancet. 2012;380:651-9.

76. Semprini R, Williams M, Semprini A et al. Type 2 biomarkers and prediction of future exacerbations and lung function decline in adult asthma. J Allergy Clin Immunol Pract. 2018 Mar 30; pii: S2213-2198(18)30137-5. doi: 10.1016/ j.jaip.2018.03.004. [Epub ahead of print].

77. Ortega HG, Yancey SW, Mayer B et al. Severe eosinophilic asthma treated with mepolizumab stratified by baseline eosinophil thresholds: a secondary analysis of the DREAM and MENSA studies. Lancet Respir Med. 2016;4:549-56.

78. Corren J, Parnes JR, Wang L et al. Tezepelumab in adults with uncontrolled asthma. N Engl J Med. 2017;377:936-46. 